
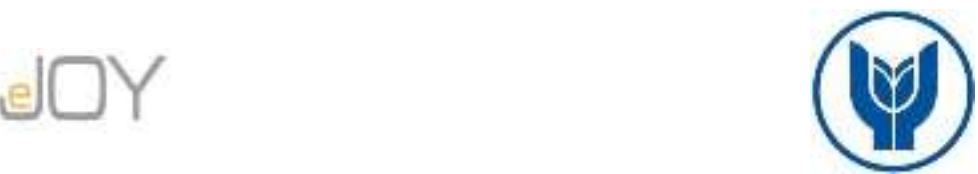

Erol Fidan, M., Bat, B. / Journal of Yasar University, 2021, 16/60, 192-214

\title{
Doğrudan Temin Yöntemiyle Yapılan Alımlarda Olası Hata ve Hile Riskleri: Bir Kamu Kurumu Örneği ${ }^{1}$
}

\section{Possible Risks of Error and Fraud in Purchases Via Direct Procurement: A Public Institution Case}

Meral EROL FIDAN Bilecik Şeyh Edebali Üniversitesi, Türkiye, meral.fidan@bilecik.edu.tr

Orcid No: 0000-0002-3954-676X

Bilal BAT, Bilecik Şeyh Edebali Üniversitesi, Türkiye, bilalbat@gmail.com

Orcid No: 0000-0000-2736-0781

Öz: Kaтu alımlarını düzenleyen Kamu Ihale Mevzuatı ve ikincil düzenlemeler kamu faaliyetlerinin kamu yararı adına sağllkl bir biçimde yürütülmesini amaçlanmaktadır. Kamu kurumları ile serbest piyasa arasındaki organik bağı oluşturan alım yöntemi ise doğrudan temin tedarik yöntemidir. Çalışmada 4734 sayılı Kamu İhale Kanunun 22/d maddesi kapsaminda yapllan alımlarda oluşabilecek hata ve hile risklerinin tespit edilmesi amaçlanmıştır. Bu amaçla genel bütçeli bir kamu kurumunun 2014-2018 yılları arasında gerçekleştirdiği doğrudan temin yöntemi ile yapılan 659 adet alım dosyası incelenmişstir. Araştırmaya konu edilen kamu kurumunun bu alımların 5018 sayll Kamu Mali Yönetim ve Kontrol Kanunu ile belirlenmiş muhasebeleştirme ve raporlama kurallarına göre gerçekleştirdiği ve 2 vaka hariç tüm alımlarında yönteme uygun işlemler gerçekleştirdiği tespit edilmişstir. Kamu alımlarında hata ve hile riskinin tamamen ortadan kaldirma çabasının çok fazla mevzuat değişikliğine, bürokrasinin artmasina, işleyişin yavaşlamasına ve kirtasiyeciliğin artmasina sebebiyet vereceği düşünülmektedir. Ancak doğrudan temin alım yönteminin özelliğinden kaynaklanan kolaylkklar bazen kamu kurumlarl aleyhinde oluşabilecek hata ve hile risklerini de beraberinde getirebilmektedir.

Anahtar Kelimeler: Kamu Harcaması, Doğrudan Temin, 4734 Sayll Kamu İhale Kanunu, Hata, Hile

\section{JEL Sinıflandırmast: M41, M42, M48}

Abstract: The Public Procurement Legislation and secondary regulations governing public procurement aim at conducting public activities in a healthy way for the public welfare. The procurement method that creates the organic link between public institutions and the free market is the direct procurement method. The study aimed to determine the errors and fraud risks that may occur in purchases made based on Article 22/d of the Public Procurement Law No. 4734. For this purpose, 659 purchase files made via direct procurement method by a public institution with an average budget between the years 2014-2018 were examined. It was revealed that the public institution in the study made those purchases in accordance with the accounting and reporting rules determined by the Public Financial Management and Control Law No. 5018, and that it performed transactions in accordance with the method in all purchases except 2 cases. It is thought that the effort to completely eliminate the risk of error and fraud in public procurements will result in too many legislative changes, longer bureaucratic processes, slower operations and increased paperwork. Conveniences thanks to the nature of direct procurement method may, however, sometimes bring about the risks of error and fraud that may go against public institutions.

Keywords: Public Expenditure, Direct Procurement, Public Procurement Law No. 4734, Error, Fraud

JEL Classification: M41, M42, M48

\section{Giriş}

Kamu harcaması, devletin vatandaştan elde ettiği gelirleri yine vatandaşın ihtiyaçlarını karşılamak ve refah düzeyini artırmak için kullandığı bir araçtır. Küreselleşmenin de etkisiyle kamu kurumlarından hizmet alan vatandaşların ihtiyaçlarının ve beklentilerinin artmasıyla

\footnotetext{
${ }^{1}$ Bu makale "Kamu Harcama Sürecinde Uygulanan Tedarik Usullerinin Hile Riski Açısından Analizi- Bir Kamu Kurumu Örneği” başlıklı yüksek lisans tez çalışmasından türetilmiştir.
} 
kamu kurumlarının beklenti ve ihtiyaçları karşılamak için hizmet standartlarını artırma gereğini doğurmuştur. Kamu kurumları hizmetlerini yerine getirebilmek için gereken mal ve hizmetleri en kaliteli, en ekonomik ve en uygun şartlarda karşılayabilme gereği duymaktadır. Türkiye'deki tüm kamu kurumlarının alımlarını aynı standartta yapabilmesi için kanun koyucu yaptığı düzenlemelerle uygulamaları bir kurala bağlamıştır. Bu kapsamda 4734 sayılı Kamu İhale Kanunu (KIK)'un 21'inci maddesi pazarlık usulü, 19'uncu maddesi açık ihale usulü, 20'inci maddesi belli istekliler arasında olmak üzere üç ihale usulüne, KİK 22'inci maddesi kapsamında doğrudan temin ve 3'üncü maddesi kapsamında istisnalar başlığı altında iki alım usulü olmak üzere beş tedarik yöntemine yer verilmiştir.

Devlet harcaması sadece devleti ilgilendiriyor gibi gözükse de aslında ülkenin ekonomik sisteminin temel taşını oluşturmaktadır. Yıllık olarak devletin harcama rakamlarının büyüklüğü göz önüne alındığında devletin yüklenicilerden satın aldığı mal ve hizmetlerin tutarı da yüksek olmakta ekonomide domino etkisi yaratmaktadır. Yapılan harcamaların parasal tutarlarının yüksek olması dolayısıyla bireylerin kişisel çıkarları ön plana çıkarak kamu alımlarına hile karışabilmektedir.

Devletin görevi gereği vatandaşın ihtiyaçlarını karşılarken yapmış olduğu harcamalar, serbest ekonomide farklı sonuçlar doğurmaktadır. Ülkede ekonomik dengenin ve büyümenin sağlanması, istihdamın yükseltilmesi ve milli gelirin eşit olarak dağıtılması büyük önem arz etmektedir (Ertaş, 2010: 17). Devlet harcamalarının yapılabilmesi için gereken kaynakları vergiler ve kamu kurumlarınca alınan harçlar vb. gelirler oluşturmaktadır. İktisadın temeli sınırsız ihtiyaçların sınırlı kaynakla karşılanmasıdır. Kamu kurumlarının ihtiyaçları sınırsız ancak kaynaklar sınırlıdır. Bu nedenle kamu kaynakların etkin ve verimli olarak kullanılması önemlidir. (Kaplan, 2012: 21).

Çalışmanın amacı, KİK 22'inci maddesi ile yapılan alımlar sonucunda oluşabilecek hile risklerini bir kamu kurumunun gerçekleştirdiği alımlar kapsamında inceleyerek, gerçekleşen ve gerçekleşebilecek risklerin giderilmesi için çözüm önerileri sunmaktır. Çalışma kapsamında İçişleri Bakanlığına bağlı bir kamu kurumunun 2014-2018 yılları arasında gerçekleşmiş ve tamamlanmış olan 1574 adet alımında doğrudan temin usulü ile ilgili olan 659 adet dosyanın incelemesi yapılmış, alımlardaki ödeme emirleri ve ekli belgeler yöntem kapsamında hile riski açısından değerlendirilmiştir.

\section{Kamu Harcaması ve Türkiye'deki Uygulama}

5018 sayılı Kamu Mali Yönetim ve Kontrol Kanunu (KMYKK)'nda kanun koyucu kamu giderini; Kanunlara veya Cumhurbaşkanlığg kararnamelerine dayanılarak yaptırılan iş, alınan mal ve hizmet bedelleri, sosyal güvenlik katkı payları, borç faizleri, borçlanma genel 
giderleri, borçlanma araçlarının indirimli satışından doğan farklar, transferler, verilen bağış ve yardımlar ile diğer giderler olarak tanımlamıştır (KMYKK, Sayı: 25326).

Türkiye'de kamu alımlarının geçmişi Osmanlı dönemine kadar dayanmaktadır. 1857 tarihli Nizamname ile Osmanlı döneminden bu yana devlet ihale sisteminin yasal düzenlemelerle yapılması zorunluluğu başlamıştır. 1914 yılında ek bir nizamname ile bazı yapım işlerinin ve satın almaların bakanların izniyle ihaleye çıkılmaksızın yapılması usulü uygulanmaya geçilmiştir. 1921'de uygulamaya geçilen bir kararname ile de 1914 tarihli Nizamname düzenlenerek merkez kamu kurumları ile İstanbul'daki şubelerinin ve İstanbul'daki askerî kurumların ihtiyacı olan ve 500 lirayı aşan tutarda mal veya levazımların Maliye Bakanlığında kurulmuş bir komisyon onayıyla temini kabul edilmiştir. Böylece alımlarda merkezileştirilme uygulaması başlatılmıştır (Akdoğan, 2014: 690).

29 Ekim 1923'ten bugüne kadar ülkemizde dört yasal düzenleme yapılmıştır. İlki 22 Nisan 1925 tarihli Hükümet Namına Vuku Bulacak Müzayede ve Münakaşa ve İhalât Kanunu'dur. Sonra 2 Haziran 1934 tarihinde Artırma, Eksiltme ve İhale Kanunu uygulamaya geçilmiştir. 8 Eylül 1983 tarihinde Devlet İhale Kanunu ve son olarak 4 Ocak 2002 tarihinde ve Kamu İhale Kanunu yürürlüğe konulmuştur (Büber, 2014: 94).

2886 say1lı Devlet İhale Kanunu 2000 y1lından bugüne yürürlükte olup, Türkiye'nin Avrupa Birliği (AB) üyeliği görüşmeleri sürecinde, Dünya Ticaret Örgütüyle ve Uluslararası Para Fonu ile yürüttüğü ilişkilerde yetersiz kaldığı görülmüştür (Akdoğan, 2014: 692). 2886 sayılı Kanunun özellikle şeffaflık ve rekabet gibi unsurlarda yetersiz kalması nedeniyle kamu alımları için yeni bir kanun hazırlanmış, 22 Ocak 2002 tarihinde KİK yürürlüğe alınmıştır. Fakat 2886 sayılı Kanunda yer alan, devlete gelir sağlayan satış, kira ve trampa işlemleriyle ilgili olan maddeler yürürlükten kaldırılmamıştır. KİK'nın yürürlüğe girmesiyle kamu alım ve satım işlemlerine ilişsin mevzuat birbirinden ayrılmıştır (Kaplan, 2012: 21-22).

Kamu harcamalarının yapılmasında kullanılan temel mevzuat olan KMYKK, KİK, 4735 Sayılı Kamu İhale Sözleşmeleri Kanunu (KİSK), 926 sayılı Türk Silahlı Kuvvetleri Personel Kanunu Cari Yı1ı Bütçe Kanunu, 657 Sayılı Devlet Memurları Kanunu, Merkezi Yönetim Harcama Belgeleri Yönetmeliği, Merkezi Yönetim Harcama Belgeleri Yönetmeliği Tebliğleri, Genel Yönetim Muhasebe Yönetmeliği, Parasal Sınırlar ve Oranlar Hakkında Tebliğ, Kamu İhale Tebliğlerine aşağıda kısaca değinilmiştir.

2003 yılında yürürlüğe giren KMYKK kamu maliyesinin anayasası niteliğindedir ve uluslararası standartlara ve AB normlarına uygun bir kamu malî yönetim ve kontrol sisteminin oluşturulmasını sağlamıştır. KMYKK ile şeffaflığın sağlanması, sağlıklı işleyen bir hesap verme sisteminin kurulması, kamu kaynaklarının israfının önlenmesi sağlanmaya 
çalışılmıştır. Uluslararası muhasebe düzenine göre işlemler uyumlaştırılmakla birlikte, kamuda idare faaliyet raporu, mahalli idareler için İçişleri Bakanlığınca değerlendirme raporu ve Maliye Bakanlığınca genel faaliyet raporu düzenlenmesi öngörülmekte ve sağlanan bu raporlar vasıtasıyla istatistiklerin kamuoyuna düzenli olarak açıklanması amaçlanmıştır (KMYKK, Say1: 25326).

30.07.2003 tarihinde 4964 Sayılı Bazı Kanunlarda Değişiklik Yapılması Hakkında Kanun'un 12'inci maddesi ile KİK'nın 18. maddesinin (d) bendi metinden çıkarılmıştır. Kanunun 22'inci maddesinde belirtilen durumlarda kamu alım ihtiyaçlarının ilân yapılmaksızın ve teminat alınmaksızın doğrudan temin yöntemiyle alımı yapılabilir denilmektedir. Yapılacak alımlarda, ihale komisyonu kurma zorunluluğu bulunmaksızın, ihale yetkilisince görevlendirilecek kişi veya kişiler tarafından piyasada fiyat araştırması yapılarak ihtiyaçların temin edilebileceği de belirtilmektedir (Bazı Kanunlarda Değişiklik Yapılması Hakkında Kanun, Kanun No: 4964).

Her yıl kamu kurumlara verilecek bütçenin belirlenmesi ve belirlenen bütçenin hakkıyla kullanılması için bu dağılım miktarı ile yeni yılın ekonomi sistemi Türkiye Büyük Millet Meclisinin (TBMM) onayına sunularak cari yıl Merkezi Yönetim Bütçe Kanunu (MYBK) yayımlanır. Bütçe Kanunu en geç ilişkili olacağı yıla bağlayan ayın son günüde yürürlüğe konmalıdır. MYBK, merkezi yönetim kapsamındaki kamu kurumlarının gelir ve gider tahminlerini gösteren, bunların uygulanmasına izin veren kanundur (KMYKK, Sayı: 25326).

KMYKK'nın 33'üncü maddesine dayanılarak hazırlanarak 2005 yılında yayınlanan Merkezi Yönetim Harcama Belgeleri Yönetmeliği (MYHBY)'nin amacı merkezi yönetim kapsamındaki kamu idarelerinde mali işlemlerin gerçekleştirilmesi ve muhasebeleştirilmesi kapsamında, harcamalarda ödeme belgesine bağlanacak kanıtlayıcı belgeleri, şekil ve türlerini belirlemektir. MYHBY devletin giderlerini karşılamak için yaptığı harcamalarda uygulanabilecek tedarik türlerinin ve bunlardaki hile riskinin en aza indirilmesi için düzenlenen önemli bir yönetmeliktir. Çünkü alım yapıldıktan sonra ilgili yükleniciye yapılacak ödeme için gereken kanıtlayıcı belgeleri düzenlemektedir. Bu yönetmelikte yer alan eksik hususlar hile riski oluşturmakta, harcama yapan kuruma gerçeği yansıtmayan alım yapma imkânı sağlamaktadır.

Kamu kurumlarınca en çok kullanılan ve hile riski açısından en riskli tedarik şekli olan KİK'nın 22/d maddesi kapsamında yapılacak mal ve hizmet ile yapım işi bedellerinin ödenmesinde aranacak belgeleri MYHBY'nin 63. maddesinde (MYHBY, Say1: 26040);

1. Fatura,

2. Düzenlenmesi gerekli görülmüş ise sözleşme,

3. Piyasa Fiyat Araştırması Tutanağı, 
4. Onay Belgesi,

5. Muayene ve kabul komisyonu tutanağı, kabul işleminin idarece yapılması halinde ise idarece düzenlenmiş belge,

6. Mal ve malzeme alımlarında, taşınır işlem fiși, olarak belirlenmiştir.

MYHBY'nin uygulanmasında kamu idarelerinde oluşan tereddütlerin giderilmesi, uygulama birliğinin sağlanması ve mevzuat değişiklikleri nedeniyle 2007 yılında Muhasebat Genel Müdürlüğü Genel Tebliği yayımlanmıştır. Bu tebliğ kamu harcamalarının ödemesinin yapılması ve hile riskinin azaltılması için ödeme emri belgesinin ekine eklenmesi gereken temel belgeler olan harcama talimatı, ihale onay belgesi, fatura ve taahhüt dosyasının hazırlanma süreci ve içeriğinde bulunması gerekenler yer aldığından kamu harcama süreci açısından önem arz etmektedir.

2014 tarihinde yayınlanan Genel Yönetim Muhasebe Yönetmeliği ile genel yönetim kapsamındaki kamu kurumlarının, hesaplarında tekdüzenin sağlanarak, kayıtlarında şeffaflık ve hesap verilebilirlik, faaliyetlerin güvenilir bir şekilde muhasebeleştirilmesinin sağlanması amaçlanmıştır. Ayrıca finansal raporların zamanında, standartlara uygun, bilgi ihtiyaçlarını doğru ve güvenilir bir şekilde karşılayacak, karar, kontrol ve hesap verme süreçlerinin etkili çalışmasını sağlayacak şekilde hazırlanarak yayımlanmasına ilişkin usul ve esasların oluşturulması amaçlanmıştır (KMYKK, Sayı: 25326).

Parasal Sınırlar ve Oranlar Hakkında Tebliğler her mali yılbaşında yayımlanarak KMYKK ve diğer mevzuat kapsamında uygulanacak olan parasal sınırları ve faiz oranlarını belirlemektedir. Türkiye İstatistik Kurumu tarafından açıklanan kamu ihale tebliğleri ilgili yılın aralık ayı yurt içi üretici fiyat endeksi yıllık değişim oranına göre güncellenerek cari yılın ihale sisteminin gereksinim duyduğu eşik değerlerin ve parasal limitlerin yenilenmesi sağlanmaktadır.

Tablo 1. 2014-2018 Yıllarında Doğrudan Temin Yöntemiyle Gerçekleştirilen Kamu Alımları Tutarları (1.000 TL)

\begin{tabular}{|r|r|r|r|r|r|r|r|r|r|}
\hline Yıllar & Mal Alımı & $\%$ & $\begin{array}{c}\text { Yapım } \\
\text { İși }\end{array}$ & $\%$ & $\begin{array}{c}\text { Hizmet } \\
\text { Alımı }\end{array}$ & $\%$ & $\begin{array}{c}\text { Danışmanlık } \\
\text { Hizmeti } \\
\text { Alımı }\end{array}$ & $\%$ & Toplam \\
\hline 2014 & 5.242 .381 & 70,65 & 273.338 & 3,68 & 1.671 .716 & 22,53 & 232.548 & 3,13 & 7.419 .983 \\
\hline 2015 & 2.078 .383 & 60,61 & 224.322 & 6,54 & 1.117 .307 & 32,59 & 8.856 & 0,26 & 3.428 .871 \\
\hline 2016 & 2.249 .199 & 58,91 & 217.110 & 5,69 & 1.341 .993 & 35,15 & 9.440 & 0,26 & 3.817 .742 \\
\hline 2017 & 2.239 .287 & 68,14 & 214.114 & 6,52 & 821.276 & 24,99 & 11.555 & 0,35 & 3.286 .233 \\
\hline 2018 & 1.884 .602 & 49,76 & 210.458 & 5,56 & 1.684 .693 & 44,48 & 7.769 & 0,21 & 3.787 .522 \\
\hline
\end{tabular}

Kaynak: KÍK, 2019,2018,2017,2016,2015 Yillarında yayınlanan raporlardan derlenmiştir.

Doğrudan temin ile yapılan mal ve hizmet alımlarının toplam alımların ortalama \%93'ünü oluşturduğu Tablo 1'de görülmektedir. Yapım işlerinin yüksek bedelli olması ve 
tamamlanmasının uzun zaman alması nedeniyle doğrudan temin yöntemi ile kıyaslandığında karşılanan oran ve tutar bazında çok düşük seviyelerde kaldığı söylenebilir.

Taşra teşkilatlarında harcama yetkisi bulunan kamu kurumları kullanacakları tedarik usullerini belirlerken amaçları şeffaf, hesap verilebilir ve hile riskinden uzak olması gibi ölçütleri göz önünde bulundurması gerekirken, en az bürokrasiyle alımı nasıl tamamlarız düşüncesi ile belirlenmektedir. Kamu kurumlarının bu düşüncesi de kanunda belirtilen ihale usulü olmayan ancak tedarik usulü olan doğrudan temin alım usulü ile gerçekleştirmektedir. Bu kapsamda 2018 yılında ihale usulü ile yapılan alımlar ile ihale usulü dışı yapılan alımların kıyaslama tutarları Tablo 2'de gösterilmiştir. Verilere göre doğrudan temin usulü kapsamındaki alımların diğer usullere kıyasla tutarının düşük olduğu görülmektedir. Tutar düşük olmakla birlikte risk açısından hata ve hileye maruz kalmadığı düşünülmemelidir.

Tablo 2. Kamu Alımlarının Kanun Kapsamına Göre Dağılımı

\begin{tabular}{|l|c|c|c|c|}
\hline \multirow{2}{*}{ Kamu Alımı Kanun Kapsamı } & \multicolumn{2}{|c|}{2018 Y1lı Miktarı } & \multicolumn{2}{c|}{2018 Y1lı Kamu Alım } \\
\cline { 2 - 5 } & Adet & Yüzde & Tutar (TL.) & Yüzdesi \\
\hline İhale Usulleri Kapsamında & 77.568 & 79,29 & 174.990 .037 & 86,58 \\
\hline Doğrudan Temin & - & - & 3.787 .522 & 1,87 \\
\hline İstisnalar & 20.258 & 20.71 & 23.337 .280 & 11.55 \\
\hline Toplam & 97.826 & 100,00 & 202.114 .839 & 100,00 \\
\hline
\end{tabular}

Kaynak: KIK, 2019 (Kamu Alımları İzleme Raporunda yer alan veriler kullanılarak hazırlanmıştır.)

Uygulamada doğrudan temin usulü alımlarda yaşanan sıkıntılardan önemli bir kısmını çözebileceği düşünülerek en son 10 Haziran 2020 tarihinde Resmi Gazete'de yayınlanan 2645 sayılı Karar yayımlanmıştır. Karar'a göre; KMYKK'da ekli cetvellerde yer alan kamu kurum ve kuruluşlarının, Devlet Malzeme Ofisi Genel Müdürlüğ̈̈ (DMO) ana statüsünde sayılan mal ve hizmetlerden, Hazine ve Maliye Bakanlığınca belirlenerek ilan edilecek olanları, ilanda belirtilen tarihten itibaren DMO aracılı̆̆lyla temin etmeleri zorunludur şeklinde karara bağlanmıştır (Resmi Gazete, 2020, Sayı: 31151).

\section{Doğrudan Temin Yönteminde Yetki ve Sorumluluklar}

5018 sayılı Kanun ile kamu harcama sürecinin yetki ve sorumluluk dengesi kurulmuş, muhasebe yetkilisinin sorumluluğu azaltılarak, kamu idareleri yöneticilerinin sorumluluğu arttırılmıştır. Böylece icraat görevlilerinin, mali sorumluluğu üstlenmeleri ve ön mali kontrol yükümlülüğünün kamu idareleri bünyesinde toplanması sağlanmıştır (Altuğ, 2018: 108). 


\subsection{Harcama / İhale Yetkilisi}

Harcama / ihale yetkilisi KMYKK'da; bütçeyle ödenek tahsis edilen her bir harcama biriminin en üst yöneticisi harcama yetkilisidir şeklinde belirtilmiştir. KİK'ya göre ihale yetkilisi, idarenin ihale ve harcama yapma yetki ve sorumluluğuna sahip kişi veya kurulları ile usulüne uygun olarak yetki devri yapılmış görevlileri olarak tanımlanmıştır (md. 4). Bir kamu satın alım surecinde, alım kararının verilmesi, alımın hangi usul ile gerçekleştirileceği, kimlerin görev alacağı gibi hususlar harcama / ihale yetkilisi tarafından verilmekte ve yine onun imzalayacağı ödeme belgesinden sonra hak sahiplerine ödeme işlemi gerçekleştirilmektedir (KMYKK, Sayı: 25326). Doğrudan temin sürecinin harcama yetkilisinin gözetimi ve denetimi kapsamında vereceği emir ve talimatlarca yürütülmesi gereğinden bahsedildiğinden, harcama yetkilisinin idari ve mali anlamda önemli bir sorumluluğunun olduğu söylenebilir.

\subsection{Gerçekleştirme Görevlisi}

Gerçekleştirme görevlisi, harcama talimatı doğrultusunda yapılması gereken işin yerine getirilmesi, mal veya hizmetin alınması, teslim ile ilgili işlemlerde teslimatın uygun bir şekilde yapılması, belgelendirilmesi ve ödeme için gerekli evrakların hazırlanması gibi işlemlerin yürütülmesinden sorumlu olan kamu personelidir. Gerçekleştirme görevlisinin kim olacağına harcama yetkilisi karar verir (KMYKK, Sayı: 25326). Ödeme emri belgesi düzenlemekle görevli gerçekleştirme görevlileri, yaptıkları veya yapmaları gereken iş ve işlemlerin doğru aktarılmasının yanında, mevzuata uygunluğundan da harcama yetkilisi ile birlikte doğrudan sorumludurlar (Sayıştay Kararları, 2008: 11).

\subsection{Yaklaşık Maliyet Tespit Komisyonu}

KİK madde 9'da; mal veya hizmet alımları ile yapım işlerinin ihalesi yapılmadan önce idarece, her türlü fiyat araştırması yapılarak katma değer vergisi hariç olmak üzere yaklaşık maliyet belirlenir ve dayanaklarıyla birlikte bir hesap cetvelinde gösterilir. Yaklaşık maliyete ihale ve ön yeterlik ilanlarında yer verilmez, isteklilere veya ihale süreci ile resmi ilişkisi olmayan diğer kişilere açıklanmaz (KİK, 24648).

\subsection{Piyasa Fiyat Araştırma Yetkilisi}

KİK'ya göre; ihale yetkilisince görevlendirilecek kişi tarafından piyasada fiyat araştırması yapılarak, amir hükmü uyarınca piyasa araştırma yetkilisinin görevlendirilmesi ihale yetkilisince yapılmalıdır. Burada önemli olan husus, görev tevdi edilen kişilerin alımlardan sorumlu tutulabilmeleri için görevlendirmenin yazılı olarak yapılmasıdır. Görevlendirme yazılı olur verilmesi şeklinde ayrı yapılabileceği gibi onay belgesi üzerinde 
görevlendirilmenin yapıldığının belirtilmesi ile de yapılabilir. Ancak piyasa araştırma yetkilisinin nasıl belirleneceğine yönelik mevzuatta herhangi bir düzenleme yoktur.

\subsection{Muayene Komisyonu}

Alım heyetinden farklı kişilerden oluşan muayene komisyonu tarafından alınan mal veya yapım / hizmet işlerinin muayenesi yapılmaktadır. Muayene heyeti, onay belgesi aşamasında belirlenen teknik özelliklerine göre alınan işleri kontrol ederek işin uygun olup olmadığına karar verir. Kontrol edilen işe yapım veya hizmet alımı olması durumunda ayrı olarak kontrol teşkilatı oluşturulur. Uygun olması durumunda saymanlık tarafından taşınır mal işlem belgesi düzenlenerek diğer belgelerle beraber ödeme yapılmak üzere maliye şube müdürlüğüne gönderir (Mal Alımları Denetim Muayene ve Kabul İşlemlerine Dair Yönetmelik Sayı: 24968).

\section{Hata ve Hile}

Hile, bir kişiye veya kuruma ait varlığına el koyma veya varlığın haksız bir şekilde kullanılması şeklinde tanımlanabilir. Bir çalışanın çalıştığı işletmenin varlık veya kaynaklarını kasıtlı olarak uygunsuz şekilde kullanarak veya ele geçirerek kendi şahsına haksız kazanç sağlamasıdır (Pehlivanlı, 2011: 3). Hile, işletme varlık ve kaynaklarının işletme personelince olduğundan farklı, eksik veya hiç gösterilmemesi, kanuna uygun olmayan veya etiğe aykırı şekilde işletmeden alınarak kişisel çıkarları için kullanılmasıdır. Hileler kasıtlı bir şekilde, önceden tasarlanarak yapılan eylemlerdir (Küçük, 2008: 3). Hilenin genel olarak aşağıdaki unsurları içermesi gerekmektedir (Bozkurt, 2016: 60).

- Hile, hileyi yapan tarafindan gizlice yapılmakta veya sürdürülmektedir.

- Hilekâr kendisine veya anlaşmalı ilişkili olduğu birine yarar sağlamaktadır.

- Hile kasitlı olarak yapılmaktadır (kasit yoksa ihmal veya hata vardır).

- Hileye maruz kalan kişi veya işletme bir şekilde aldatılmakta ve zarara uğratılmaktadır.

Yönetim, üst yönetimden sorumlu olanlar, çalışanlar veya üçüncü kişilerden bir veya birden fazla kişinin, haksız veya yasalara aykırı bir menfaat elde etmek amacıyla yaptığı aldatma içeren kasıtlı faaliyetlere hile denilmiştir (KGK, 2013: 9).

Muhasebede hata kavramı; muhasebe sisteminde kasitl olmayan fiiller sonucu ortaya çıkan durumlar şeklinde tanımlanmaktadır (Baskan, 2013: 21). Belli bir amaç için işletmenin işlem, kayıt ve belgelerinin kasıtlı olarak tahrif edilmesine muhasebe hileleri denir. Hile, bir ya da daha fazla kişinin bilinçli olarak bir varlığın değerinden azaltarak, gizlice kendi zenginleşmelerine katkıda bulunmaları olarak ifade edilirken, muhasebe hataları bilgi 
yetersizliği ve dikkatsizlikten kaynaklanmasına rağmen; muhasebe hileleri, kasıtlı olarak gerçekleşmektedir (Çatıkkaş ve Çalış, 2010: 148).

\section{Doğrudan Temin Yönteminin Hata ve Hile Riski Açısından Değerlendirmesi}

Doğrudan temin yöntemi 4734 sayılı Kanun metninin 18'inci maddesinin (d) bendinde ihale usulleri arasında sayılmış olmasına rağmen 30 Temmuz 2003 tarih ve 4964 sayılı Kanun'un 12 'inci maddesiyle diğer ihale usullerine göre önemli farklılıklar içerdiği ve esasen bir ihale usulü olmadığı gerekçesiyle kanun metninden çıkarılmıştır. Bu kapsamda ihale usullerinden çıkarılan doğrudan temin usulü; ihale yetkilisinin görevlendirdiği kişi ya da kişilerce teknik şartların ve fiyatın görüşülmesiyle ihtiyaçların gerçekleştirildiği bir alım usulü olarak uygulanmaktadır (KİK, Sayı: 24648).

Dolayısıyla yasa kapsamındaki idareler, Kanun'un 22'inci maddesi kapsamında gerçekleştirecekleri işlerini anılan maddeye istinaden saydamlık, rekabet, eşit muamele, güvenirlik, gizlilik, kamuoyu denetimi, ihtiyaçların uygun şartlarla ve zamanında karşılanması temel ilkeleri dışında tedarik etmelerine imkân tanınmıştır.

Doğrudan temin usulü, mevzuatta belirtilen esaslarla birlikte uygulandığında idarelerin karşılanması güç ve acil ihtiyaçlarını daha kısa bir zamanda ve bürokratik engellere takılmadan karşılamasında büyük bir kolaylık sağlamıştır. Ancak bu kolaylıklar, mevzuatta belirli şartların gerçekleştiği durumlar için sınırları belirlenerek kullanılma imkânı vermektedir. Esas alım usulü olarak açık ihale usulü belirtilmiş olmakla birlikte, şeffaflık ve açıklık gibi ilkelerin uygulanmadığı doğrudan temin usulünün ise bir nevi özel alım faaliyeti olarak anlaşı1masının gerektiği vurgulanmıştır (Atılbaz, 2009: 106).

Günümüzde doğrudan temin alım yöntemi kanun gerekçesinde açıklanan amacından kısmen uzaklaşmıştır. Ayrıca doğrudan temin alım yönteminin KİK içerisinde yer almasına rağmen bir ihale usulü olmaması zaten karışık bir paradokstur. Kanunda açıklanan özel durumlar hile riski açısından aşağıda irdelenmiştir:

- Hile riski açısından en riskli kısım, ihtiyacın tedarik edileceği firmanın ve tedarik tutarının belirlenmesi kısmıdır. Yönetmelik bu işlem için piyasa fiyat araştırma tutanağını yeterli görmüştür. Teklif mektubu, yaklaşık maliyet veya benzeri bir evrak istememesi hile riskinin artmasına sebebiyet vermektedir (MYHBY: Say1: 26040).

- KİK 22/a maddesi kapsamında gereksinimlerin yalnız bir firma tarafindan tedarik edilebileceği zorunluluğu nedeni ile yapılacak tedariklerde işi yapabilecek firmanın tespitinde sadece kamu kurumunun bulunduğu ildeki firma istekli olarak dikkate alınmaktadır. Diğer illerde ihtiyacı karşılayabilecek yüklenici olup olmadığı genellikle araştırılmamaktadır. Aynı işi yapan firmalar olduğu bilinse dahi kanunu bu şekilde yorumlamak idarelerin işine 
gelmektedir. Kurumun bulunduğu ildeki esnafın desteklenmesi gerektiğini düşünen kurum yetkililerinin çokluğu da bu piyasa fiyat araştırmasının sadece bulunulan il sınırlarında yapılmasinı arttırmaktadır.

- Alım sürecinde yaklaşık maliyet komisyonu üyelerince yapılan araştırma neticesinde fiyatlar ilgili firmalardan teklif mektubu şeklinde alınabileceği gibi sözlü olarak alınarak ya da internet fiyatlarının tutanağa geçirilmesi suretiyle de alınabilmektedir. Kamu kurumunun yer aldığg il veya ilçede tedarik konusu hizmeti karşılayabilecek tek isteklinin var olması, KİK yönteme uygun olarak tedarik edilmesi için geçerli bir neden meydana getirmemektedir. Kamu kurumu yetkililerince bu durumun dikkate alınmaması sebebiyle sabit firmalarla devamlı olarak kurum ihtiyaçları tedarik edilmekte ve hile riskine açık bir ortam yaratılmaktadir.

-Eşik değerlerin altında kalmak amacıyla mal veya hizmet alımları ile yapım işleri kısımlara bölünemez. Eşik değerler ile parasal limitlerin kamu ihale tebliği ile tespit edilmesiyle doğrudan temin limiti büyükşehirler ve diğer iller olmak üzere güncellenir. Büyükşehirlerde bu limitin yüksek olması kamu kurumlarını KİK'nın 19'uncu maddesinden uzaklaştırmakta, hatta yapılacak alımlarının bölünerek alınmasına sebebiyet vermekte ve kamu kurumlarını hile riski açısından en riskli alım usullerinden olan doğrudan temin yöntemine sevk etmektedir. Acil ihtiyaç duyulan mal ve hizmet alımlarının faturalarının bölünme işlemine tabi tutularak doğrudan temin yöntemiyle yapılabilir olması doğrudan temin ile ilgili uyulması gereken kuralların yeterince açık olmamasından ve kural ihlali halinde uygulanacak cezai müeyyidelerin belirtilmemesinden kaynaklanmaktadır.

- Kanunda geçen tek kaynaktan temin edilen mallara veya hizmetlere ilişkin formu hazırlanırken dikkat edilmesi gerekenler belirtilmektedir. Buna göre alımın gerçek veya tüzel tek kişiden yapılma sebepleri ayrıntılı, net ve objektif bir biçimde ortaya koyularak, doğrudan temin 22'inci maddesinde belirtilen hükümlerin uygulanabilir olmasını sağlayan nedenler ayrıntılı olarak yazılacak ve alım konusuyla ilgili belgeler de bu forma eklenecektir denmektedir. Mal alımlarında ihtiyacın niteliği, ihtiyaç konusu malın teknik ayrıntısı ve ne amaçla kullanılacağı, bu mala emsal olabilecek ürünlerin bulunup bulunmadığının araştırmasının yapılıp yapılmadığı ve bulunamıyorsa sebepleri, alınacak malı satan başka satıcıların olup olmadığı gibi konulara yer verilmesi gerektiği açıklanmaktadır. Bu bende göre kamu kurumları istenilen ayrıntılı açıklamaları doğrudan temin alımlarında yeterince yerine getirmemekte ve ilgili kanun maddesi ihlâl edilmektedir. Bir taahhüt kapsamında; taahhüt konusu sözleşme veya şartnamede yer alan hükümler nedeniyle belli bir marka veya modelli 
malın alınmasının zorunlu olduğu hallerde, 22'inci maddenin (a) bendinin uygulanması mümkün bulunmaktadır.

- KİK 22/b maddesi; sadece gerçek veya tüzel tek kişinin ihtiyaç ile ilgili özel bir hakka sahip olması ve kurumun zimmetinde bulunan malın standart özelliklerinin bozulmaması amacıyla yapılan alımlarda veya garantisi bitmemiş malzemelerin veya ihtiyaçlarının karşılanması için başvuru yapılabilir denilmektedir. 22/b kapsamındaki alımlarda kamu kurumunun bulunduğu ilde birden çok yetkili firma bulunsa da, rekabet prensibine hiçbir şekilde uymayan bir davranışla herhangi bir seçim ölçütü belirlenmeden kumu kurumunun seçtiği bir firmadan ihtiyacın giderilmesi hile riski doğurmaktadır. Örneğin çalışmada incelenen kurumun faaliyet gösterdiği ilde sadece bir tane Ford yetkili servisi bulunması sebebi ile bu madde gerekçe gösterilerek alım yapılmaktadır. Çevre illerin yetkili servislerinden teklif alınmamaktadır. Ancak ilde Mitsubishi araçların yetkili servisi bulunmaması nedeniyle başka bir ilindeki yetkili servisten de alım yapılmaktadır. Duruma göre idare yetkilileri kendi işlerini kolaylaştırmak için harcama yetkilisini yönlendirmek suretiyle işlem yapılabilmektedir. Bu da hatalı ve hileli işlemlere zemin oluşturmaktadır.

- Doğrudan temin alımlarında oluşturulacak komisyonlarda yer alacak personelin görevlendirilmesi hakkında mevzuatta ayrıntılı bir düzenleme bulunmamaktadır. Harcama / ihale yetkilisi alım süreci hakkında bilgisi olmayan personele de görev verebilmektedir. Piyasa araştırma komisyonu alım konusu olan mal ve malzemeler hakkında yeterli bilgiye sahip olmadıkları için yeterli ya da hiç piyasa araştırması yapmayarak süreci harcama / ihale yetkilisinin yetkisine bırakabilmektedir. Aynı personel aynı zamanda muayene kabul komisyonunda da görevlendirilebilmektedir ve alınan malzemeleri kontrol etmeden imzalamak durumunda kalabilmektedirler. Harcama / ihale yetkilisinin ricası ya da korkusu bu görevlendirilmelerde itirazı çoğu zaman ortadan kaldırmaktadır. Bu durum da doğrudan temin yolu ile alımlarda hata ve hile unsurlarının artmasına neden olmaktadır.

- Mevzuatta işleyişin belirlenmiş usul sırasına göre yapılması gerektiği belirtilmektedir. Örneğin; yazılı onay alınmadan doğrudan temin alımlarına çıkılamayacağı veya muayene kabul işlemi yapılmadan faturalandırma aşamasına geçilmez. Fakat uygulamada sözlü onay ile alım işleminin gerçekleştirildiği ya da fatura kesildikten sonra evrakların daha sonra düzenlendiği birçok kurumda tespit edilebilmektedir. Kurumların ihtiyaçlarını karşılarken öngörülemeyen durumlarla karşılaşmaları veya bazı alımların o süreçte acil olarak yapılması gerektiği durumlarla sıkça karşılaşabilmekte ve bu durumlarda da kamu yararı gözetildiği ve harcamaların en makul seviyede gerçekleştirildiği algısı, doğrudan temin sürecini hatalı yürütmeye sebebiyet vermektedir. 


\section{Literatür İncelemesi}

Araştırma konusu ile ilgili literatür incelemesinde doğrudan temin yöntemi konulu çalışmaların çoğunluğunda yöntemin özellikleri ve eksiklikleri üzerinde durulduğu görülmektedir. Doğrudan temin yöntemini kullanan kurumların gerçekleştirdiği alımlarda karşılaşılan sıkıntıların ya da yöntemin kurumlara olan yarar ya da zararları üzerinde yapılmış uygulaması olan çalışmaların çok az olduğu görülmektedir.

Atılbaz (2009), çalışmasında doğrudan temin sürecinin uygulama alanı ve esaslarının literatür yoluyla taraması yapılmıştır. KİK'nın yürürlüğe girmesiyle ortaya çıkan problem bölgelerine ilişkin çözümler sunulmuştur. Ayrıca personelin hukukî olarak mağdur olmaması içinde hangi hususlara dikkat etmesi gerektiği belirtilmiştir.

Kartalcı (2010), çalışmasında ihale sistemimizde DMO'nun yerini ve ihale sisteminin yolsuzluğu teşvik edici yönleri açıklanmaktadır. Kamu ihale sisteminin saydamlığı, rekabeti artıran, hesap verebilirliği ve kamuoyu denetimini sağlayan bir yapıya sahip olması ve istisna hükümlerine de çok az yer vermesi gerektiği belirtilmiştir. Türk ihale sisteminin DMO’yu aşırı istisna yetkileriyle donattığı, DMO’nun alım ve satım sisteminin yolsuzluğu teşvik edici olduğu belirtilmektedir. Bunun yanında kamu kuruluşlarının, denetimden kaçmanın bir yolu olarak DMO’yu kullandığı, DMO'nun kurumsal olarak iyi yönetilmediği ve kuruluş amaçlarının günümüz şartlarında geçerliliğini kaybettiği belirtilmektedir.

Ekşi (2013), çalışmasında yolsuzluk suçları bakımından kamu ihale sisteminin kamu harcamaları içerisindeki yeri ele alınarak irdelenmiştir. Çalışmada rekabet, şeffaflık, halkoyu kontrolü, alımların makul koşullarda temin edilmesi gibi prensiplerin doğrudan temin alım usulünde çekişmeli olduğu, açık ihale usulü yerine doğrudan temin alım yöntemi kullanılarak kamu kaynaklarının verimli kullanılmasının engellendiğinin vurgusu yapılmıştır.

Özer (2015), çalışmasında kamusal harcamaların yapılmasında izlenecek tedarik sürecinde, uygulanan ihale ve alım usullerinin yolsuz hareketler açısından riskleri analiz edilerek kamu tedarik sistemi irdelenmiştir. Doğrudan temin usulünün diğer usullere göre çok fazla yolsuzluk riski taşıdı̆̆ı vurgulamıştır.

Topal (2016), çalışmasında hizmet alımlarında ihaleler yapılırken karşılaşılan sorunlar ve çözüm önerilerinden bahsedilmektedir. Bilecik İl Özel İdaresinde ihalelerde görevli çalışanlarca belirtilen sorunlar ele alınmıştır. En çok karşılaşılan sorunların başında doğrudan temin sınırıyla ilgili yaşanan sorunlar; ihaleye katılan kurumların belli bir marka belirtememesi, teklif mektuplarının dağıtılması sırasında tarafların yeterli özeni göstermemesi, personelin ihalede görev almak istememesi, yönetmeliklerin açık ve net olmaması, mal tesliminde gecikmelerin olması vb. olduğu belirtilmiştir. 
Atuğ (2018), çalışmasında doğrudan temin usulüyle yapılan alımlarda kamu görevlilerine verilen sorumluluklar incelenerek literatür taraması yapılmış ve doğrudan temin alımı sürecinde yapılan usulsüzlükler piyano alımı olarak hikayelendirilerek gerçek bir vaka anlatılmaya çalışılmıştır.

Yavuz (2018) çalışmasında doğrudan teminin, ihale usulü olmaktan çıkarıldıktan sonra hukuk dünyasına etkisini incelemiştir. Yöntemde belirtilen eşik değerlerin altında kalmak amacıyla mal veya hizmet alımları doğrudan temin yöntemi çerçevesinde irdelenmiştir. Çalışmada doğrudan temin yöntemi nedeniyle temel ihale ilkelerinden uzaklaşıldığı belirtilmektedir.

Demir (2019), çalışmasında Türkiye'de uygulanmış ihale kanunları ve yetersiz kalınan durumlar, uygulamada karşılaşılan sorunlar ve çözüm önerileri ele alınmıştır. İhale kanununun önem taşıyan yapısından ötürü sorun kabul etmeyecek uygulamalar içermesi gerektiği ihale usullerini kapsayan mevcut yasa ile ilgili günümüzde çeşitli değişikliklerin yapılmaya devam edildiği belirtilmiştir.

Üstün ve Çalış (2019), çalışmalarında doğrudan temin usulü incelenerek, özellikleri, uygulanacağı haller ve ihtiyacın bu usule başvurularak karşılanması halinde idarenin dikkate alması gereken esaslar irdelenerek, bu hususa ilişkin önerilere yer verilmiştir.

\section{Araştırmanın Amacı}

Çalışmanın amacı bir kamu kurumunda doğrudan temin yöntemiyle gerçekleşen alımları inceleyerek, bir kurumda bir dönemde bu yöntemle ne kadar alım yapılmak durumunda kalındığını ve bu alımlarda gerçekleşebilecek kural dışı uygulamaları inceleyerek hile riski açısından mevzuattaki açıkları değerlendirmek ve çözüm önerileri getirebilmektir.

\section{Araștırmanın Kapsamı ve Sınırlılıkları}

Araştırmanın kapsamını taşrada bulunan bir kamu kurumunun doğrudan temin usulü kapsamında 2014-2018 yıllarında aldığı mal, hizmet ve yapım işleri oluşturmaktadır. Bu kapsamda incelenen dosya ve alım türleri ve sayısı Tablo 3 'te gösterilmiştir.

Tablo 3. 2014-2018 Alım Usullerine Göre Dosya Sayısı

\begin{tabular}{|c|c|c|c|c|}
\hline $\begin{array}{c}\text { Alım Usulleri } \\
\text { 4734 Yıllar }\end{array}$ & $\begin{array}{c}\text { Madde 19 } \\
\text { (Dosya Sayısı) }\end{array}$ & $\begin{array}{c}\text { Madde 22/A-B } \\
\text { (Dosya Sayısı) }\end{array}$ & $\begin{array}{c}\text { 22/D } \\
\text { (Dosya Sayısı) }\end{array}$ & $\begin{array}{c}\text { İstisnalar Madde 3 } \\
\text { (Dosya Sayısı) }\end{array}$ \\
\hline $\mathbf{2 0 1 4}$ & 4 & 197 & 180 & 2 \\
\hline $\mathbf{2 0 1 5}$ & 7 & 230 & 162 & 4 \\
\hline $\mathbf{2 0 1 6}$ & 5 & 198 & 129 & 4 \\
\hline
\end{tabular}




\begin{tabular}{|c|c|c|c|c|}
\hline $\mathbf{2 0 1 7}$ & 2 & 166 & 80 & 8 \\
\hline $\mathbf{2 0 1 8}$ & 3 & 82 & 108 & 3 \\
\hline Toplam & 21 & 873 & 659 & 21 \\
\hline \multicolumn{2}{|r|}{ GENEL TOPLAM } & 1574 \\
\hline
\end{tabular}

Kaynak: Incelenen kamu kurumunun 2014-2018 yılları arası mali arşivi sayılarından derlenmiştir.

İlgili kamu kurumunun 4734 sayılı Kanun'un 19'uncu maddesi kapsamında yapılan alımları genelde kömür alımı, elektrik alımı, otomobillerin zorunlu mali sorumluluk sigortaları ve doğrudan temin limitini aşan yapım işleri oluşturmaktadır. 22/a ve b bentlerine göre arşivlenen dosyaları ise ilgili belediyelerden alınan su alımları, Türk Telekom'dan alınan hizmetler ile garanti kapsamında olan otomobillerin yetkili servislerinde yapılan bakımonarım giderlerini kapsamaktadır. 22/d kapsamında yapılan alımlar ise doğrudan temin limiti altında kalan tüm alımları kapsamaktadır. Istisnalar madde 3 kapsamında yapılan alımlar DMO'dan alınan kırtasiye malzemeleri, oto lastik alımlarını kapsamaktadır. İncelenen kamu kurumunun 2014-2018 yıllarında yaptığı alım usulleri ve miktarları incelendiğinde risk oluşturan grubun 4734 sayılı Kanun'un 22/d maddesi kapsamında yapılan alımlar olduğu görülmektedir. Araştırmada incelenen dosya sayısı 2014-2018 dönemleri arasında arşivlenmiş olan dosyalarla ve 22/d kapsamındaki alımlarla kısıtlıdır.

\section{Araştırmanın Yöntemi ve Tespit Edilen Vakalar}

Araştırma kapsamında ilgili kamu kurumunun 2014-2018 yıllarına ait arşivindeki tüm dosyalar konunun amacı doğrultusunda belge tarama yöntemiyle incelenmiştir. İncelenen dosyalar harcama türlerine, sayısına ve parasal tutarlarına göre doğrudan temin usulü açısından değerlendirilerek hata veya hile riski oluşturabilme özelliklerine göre incelenmiştir. Tespit edilen 2 vaka hikâyelendirme yapılarak açıklanmıştır.

\subsection{Vaka 1: Otomobil Onarımı ve Yedek Parça Alımı Süreci}

Kurumun kamusal görevini icra etmesinde önem taşıyan devriye araçları yıl içerisinde farklı şoförler tarafından çok fazla kullanılmaktadır. Kurumun görev alanının kırsal kesim olması nedeniyle arıza sayısı fazla olmaktadır. Kurumun X marka aracı devriye esnasında arıza yapmış görevli personelin tüm çabalarına rağmen çalıştırılamamıştır. Devriye personeli kurumun bünyesinde bulunan bakım-onarım birimine bilgi vermiş, bakım-onarım birimi çekici vasıtasıyla arızalı devriye aracının kurum içerisinde bulunan bakım-onarım birimine getirilmesini sağlamıştır. Bakım-onarım birimi bünyesinde bulunan motorlu araç teknisyeni ile aracın arızası tespit edilmeye çalışılmış, aracın onarımının bakım-onarım biriminin 
imkânları ile yapılamayacağına karar verilip, onarım belgesi ile beraber lojistik şube müdürlüğünden ihtiyaç talebinde bulunulmuştur. Lojistik şube müdürlüğünce aracın garanti kapsamında olup olmadığı kontrol edilerek aracın garantisinin bittiği tespit edilmiştir.

Lojistik şube müdürlüğü aracın arızasını piyasadan tedarik etmek için, bakım-onarım biriminin düzenlediği onarım belgesinde belirtilen arızaya göre piyasadan yaklaşı maliyet tespitinde bulunmuştur. Yaklaşık maliyet 7.850,00 TL. olarak verilmiş olup, bu limit incelenen kamu kurumunun bulunduğu ilde 2018 y1lı için 22/d limiti olan katma değer vergisi hariç 22.524,00 TL.'nin altında kaldığından KİK'nın 22/d kapsamında yapılmak üzere MYHBY'nin 4'üncü maddesinde belirtilen şartları taşıyan bir onay belgesi lojistik şube müdürü imzalı olarak hazırlanarak, harcama yetkilisinin onayına sunulmuştur. Harcama yetkilisinin alımın piyasadan tedarike onay vermesinden sonra onay belgesi ve ekli belgeler yetkilendirilmiş alım heyetine dosya ile teslim edilmiştir.

Üç kişiden oluşan alım heyeti onay belgesi ve ekli belgeleri teslim aldıktan sonra söz konusu alımın EKAP’a girişi yapılmıştır. Kurum içi yönergeler gereği en az üç adet teklif mektubu hazırlanarak piyasa araştırmasına çıkılmıştır. Teklif verme sürecinde firma yetkilisi aracın arıza bilgilerinden arıza tutarını belirleyemedikleri için arızalı aracın tamirhaneye gelmesi ve bu şekilde teklif verebileceği belirtilmiştir. Söz konusu arızalı aracın devriye aracı olmasından dolayı en kısa sürede tamir edilerek kullanılır hale getirilmesi gerekmekte olup, kurumun bakım-onarım birimi aracı özel bir servise götürerek tamir ettirmiştir. Daha sonra temin edilmesi gereken üç adet teklif mektubu da aracın tamir ettirildiği bu firma tarafından doldurularak kuruma teslim edilmiştir. Tamiri yapan firma teklifin bir tanesini ilgili onarım tutarı kadar kendisi hazırlayıp, diğer ikisini farklı firmalardan daha yüksek fiyatlarla düzenletip, imzalattırarak ilgili kuruma vermiştir. Alım heyeti bu üç teklif mektubunda yer alan firmaların yasaklılık teyidini EKAP üzerinden yapmıştır.

Alım heyeti üç teklif mektubunda belirtilen fiyatlardan en avantajlı olanı piyasa fiyat araştırma karar tutanağı tanzim edilerek harcama yetkilisinin onayına sunmuştur. Harcama yetkilisinin onayına müteakip kurum içi yönergelerde doldurulması gereken karar defterine teftişlerde incelenmek üzere kaydedilmiştir. Ayrıca ihale kanunlarına tabi olan veya olmayan resmi daire ve kamu tüzel kişiliğini haiz kurumların her türlü ihale kararları 5,69 oranında (Damga Vergisi Kanunu, Say1: 11751) damga vergisi kesilmesi hususundaki maddesi gereğince kesilerek il defterdarlığına yatırılması sağlanmış ve vezne alındısı teslim edilmiştir. $\mathrm{Bu}$ işlemlerden sonra bir başkan iki üyeden oluşan ve bu görevi ikiz olarak yürüten muayene ve kabul komisyonuna dosyayı teslim etmiştir. 
Muayene ve kabul komisyonu içerisinde teknik personel bulunmadığından bakım-onarım birimi yetkili teknisyeni tarafindan kontrol teşkilatı formu düzenlenerek muayene ve kabul komisyonuna teslim edilmesi sağlanmıştır. $\mathrm{Bu}$ form, aracın çalışır vaziyette olduğunu ve kurumun bakım-onarım birimince bu durumun teyit edildiğini göstermektedir. İlgili vakada muayene ve kabul komisyonu MHYHB gereği doldurması gereken belgeleri hazırlamıştır. Heyetçe arızalı aracın tamir edildiğini yerinde gördükten sonra tüm dosyayı Taşınır Mal Saymanlığına teslim etmiştir. Saymanlığa teslim edilen hizmet alımının gerekli kontrolleri yapıldıktan sonra onarım yapan firma faturayı kesmesi ve 6183 sayılı Amme Alacakları Kanunu'na göre alım tutarı katma değer vergisi dâhil 2.000,00 TL'yi geçtiği, 22/a kapsamında vergi borcu yoktur yazısını teslim etmesi için kuruma davet edilmiştir. Fatura tanziminden sonra hizmet yapım işi belgesi tanzim edilerek tüm dosya ödemesi yapılmak üzere teslim senedi ile beraber Maliye Şube Müdürlüğüne teslim etmiştir.

Dosya KMYKK, KİK, 488 sayılı Damga Vergisi Kanunu, 3065 sayılı Katma Değer Vergisi Kanunu, Merkezi Yönetim Harcama Belgeleri Yönetmeliğine ve kurum içi yönergelere göre mali kontrol yapılarak, kontrol sonucunda eksiklik bulunmaması durumunda ilgili gerçekleştirme görevlisi tarafından ödeme emri belgesi düzenlenerek harcama yetkilisinin onayına sunulmuştur. Harcama yetkilisinin onay vermesi halinde, ödeme emri belgesi ve eklenmesi gerekli tüm belgeler İl Muhasebe Müdürlügüne teslim edilmiştir.

KMYKK 61'inci maddesi gereğince, ödeme emri belgesi ve ekli belgeler üzerinde; yetkililerin imzasını, ödemeye ilişkin ilgili mevzuatında sayılan belgelerin tam olmasını, maddi hata bulunup bulunmadığını, hak sahibinin kimliğine ilişkin bilgileri kontrol edilip, eksik bulunmaması durumunda hazineden ödeme talep edilmek üzere ödeme emri belgesi onaylanarak ödeme işlemi tamamlanmıştır.

\subsubsection{Otomobil Onarımı ve Yedek Parça Alımının Doğrudan Temin Süreci} Açısından Değerlendirilmesi

İlgili vakada gerçekleştirilen doğrudan temin alım yöntemi kurumun kontrol teşkilatınca tepki çekmekle birlikte kurumun bakım-onarım birimi tarafından söz konusu acil duruma bir çözüm yolu olarak uygulandığı düşünülmüştür. Arızalı aracın onarımı için bakım-onarım alımı yapılmamış, aracın arızalı parçalarını temin şeklinde mal alımı olarak yöntem uygulanmıştır. Ancak yedek parça fiyatlarına işçilik maliyetleri de eklenerek üç firmadan teklif alınmış ve ödeme yapılmıştır.

Vakada ihtiyacın tespitinden yüklenicinin hesaplarına ödemenin aktarılmasına kadar geçen süreçte görev alan tüm personelin ayrı birimlerde görevli olması ve bu personellerin birbirleri ile amir-memur ilişkisi bulunmaması nedeniyle her bir süreçte görev alan personelin 
bir önceki süreci bağımsız olarak kontrol etmesinin sağlandığı tespit edilmiştir. Doğrudan teminin bir ihale yöntemi olmadığı ve EKAP'a girme zorunluluğu bulunmadığı halde şeffaf olmak için doğrudan temin ilanları EKAP' a girilmiştir.

İhale usulü olmayan doğrudan temin alım yöntemi kapsamında yapılan alımlar için piyasa fiyat araştırma tespit komisyonu ve muayene kabul komisyon üyelerinin niteliklerinin neler olacağına yasal mevzuatta yer verilmemiştir. Kurum içi yönergelerde üyelerin niteliklerine yer verilmişstir. Kurum personeli arasında bu konuda yeterli bilgiye sahip personel olmadığ ve harcama yetkilisince söz konusu komisyonlara tecrübesiz personellerden görevlendirme yapıldığı görülmektedir. İlgili kurumun özelliğinden de kaynaklı olarak usta/çırak yöntemiyle bu işler yürütüldüğünden komisyon üyelerinin mevzuat bilgisi neredeyse yok denecek kadar azdır. Tüm kamu kurumlarında olduğu gibi incelenen kamu kurumunda da harcama / ihale yetkilisi tedarik sürecinde tek yetkili güç ve süreçteki tüm personelin amiri pozisyonunda olduğundan tüm personel onun yönlendirmesi doğrultusunda hareket etmektedir.

Kurum personelinin tabi olduğu disiplin kanunu olan, 7068 sayılı Genel Kolluk Disiplin Hükümleri Hakkında Kanun Hükmünde Kararnamenin Kabul Edilmesine Dair Kanunu'na göre incelendiğinde ise yetkilendirilmiş alım heyetinin piyasa fiyat araştırmasını yaparken gerçekten üç firmadan teklif alınmadan, almış gibi gösterdiği durumdan harcama/ihale yetkilisinin bilgisi yok ise söz konusu Kanunun 8 'inci maddesi meslekten çıkarma cezasını gerektiren fiiller başlığının altında yer alan kasıtlı olarak gerçek dışı rapor vermek veya tutanak düzenleyip imza etmek veya ettirmek suçunu oluşturduğundan ilgili personel meslekten ihraç edilebilmektedir.

\subsection{Vaka 2: Bina / Çatı Bakım ve Onarımı Doğrudan Temin Süreci}

Kamu kurumlarının harcama kalemleri; çeşitleri, etkileri ve özellikleri itibariyle farklılık göstermektedir. Bu kapsamda devletin faaliyetleri hakkında bir sonuca varabilmek için kullanım alanı ve özellikleri açısından birbirine benzeyen harcamaları bir araya toplamak faydalı olacaktır. Böylelikle ekonomik nitelik ve özellikler göz önünde tutularak yapılmış bir sınıflandırma bize kamu harcamalarının milli ekonomi üzerindeki etkilerini daha iyi analiz etme olanağ1 verecektir (Aytaç, 2004: 33-34).

Bu kapsamda Hazine ve Maliye Bakanlığınca her mali yıl bütçesi hazırlıklarına esas alınmak üzere analitik bütçe sınıflandırmasına ilişkin rehber hazırlanmaktadır. Türkiye'de KMYKK'nın yürürlüğe girmesiyle birlikte Analitik Bütçe Sınıflandırma Sistemi uygulanmaya başlanmıştır. Bu rehberin birinci bölümünde ekonomik sınıflandırmanın açıklamalarına yer verilmektedir. Ekonomik I. düzey sınıflandırması Tablo 4'te görülmektedir. 
Kurum lojmanlarının B bloğunun çatısı kırık kiremitlerden ve eskiyen yapıdan dolayı akıntı yapmaktadır. İncelenen kurumun lojman yönetim kurulu onarımın yapılması için yazı ile talepte bulunmuştur. Kurumda her harcama için ekonomik düzey sınıflandırmasına göre ödenek gönderilmekte ve bu esaslar doğrultusunda harcama yapılmaktadır. Hizmet binasının çatısının onarımı için 03-2-7-22 Güvenlik ve Savunmaya Yönelik Gayrimenkul Büyük Onarım Giderleri ekonomik kodlu ödenekten ödenecektir. Ancak onarılacak çatı lojmana ait ise 03-82-01 Lojman Bakım ve Onarımı Giderleri ekonomik kodlu ödenekten ödenecektir.

Lojman yönetim kurulundan gelen talep lojistik şube müdürlüğünce Milli Emlak Genel Tebliği kapsamında kamu kurum ve kuruluşlarınca karşılanacak giderler kapsamında olup olmadığı incelenmiş ve bu onarımın bütçeden karşılanabileceğine karar verilmiştir. İlgili gider için yapılan ödenek kontrolünde 03-8-2-01 Lojman Bakım ve Onarımı Giderleri ekonomik kodunda ödenek olmadığı tespit edilmiştir. Lojistik şube müdürlüğünce merkez teşkilatından ödenek talep edilmiştir. Ödenek gelmesine müteakip harcama yetkilisinin de görüşü alınarak lojman çatısı onarımı ve hizmet binası bakımı için onay belgesi hazırlanarak, onay belgesi ve ekleri ihtiyacın tedarik edilmesi için yetkilendirilmiş alım heyetine teslim edilmiştir.

Tablo 4. Ekonomik Sınıflandırma Birinci Düzey

\begin{tabular}{|c|l|}
\hline \multicolumn{2}{|c|}{ GIDERIN EKONOMÍK SINIFLANDIRMASI I. DÜZEYİ } \\
\hline 01 & PERSONEL GIDERLERİ \\
\hline 02 & SOSYAL GÜVENLİK KURUMLARINA DEVLET PRIMİ GIDERLERİ \\
\hline 03 & MAL VE HİZMET ALIM GIDERLERİ \\
\hline 04 & FAİZ GİDERLERİ \\
\hline 05 & CARİ TRANSFERLER \\
\hline 06 & SERMAYE GİDERLERİ \\
\hline 07 & SERMAYE TRANSFERLERİ \\
\hline 08 & BORÇ VERME \\
\hline 09 & YEDEK ÖDENEKLER \\
\hline
\end{tabular}

Kaynak: 2019-2021 Analitik Bütçe Sınıflandırma Rehberinden hazırlanmıştır.

Yetkilendirilmiş alım heyeti B Blok Çatı Onarımı şeklinde yeterli açıklaması bulunmadan hazırlanan teklif mektubu ile piyasa araştırmasına çıkmıştır. Kurumun bulunduğu il küçük olduğu için firmalar kuruma gelip, işi yerinde görerek fiyat teklifi vermiştir. Bu şekilde üç firmadan teklif alınarak iş en avantajlı teklifi veren firmaya verilmiştir. Firmaca, verilen iş süresinde tamamlanarak dosya muayene ve kabul komisyonuna teslim edilmiştir. Muayene ve kabul komisyonunda ilgili konu hakkında teknik personel bulunmadığı halde firma sahibinin yönlendirmesi ile işin tamamlandığı kanaatine varılarak muayene raporu tanzim edilerek evraklar taşınır mal saymanlığına teslim edilmiştir. Taşınır mal saymanlığınca evraklar tam 
kabul edilerek firmaya fatura kesilmiştir. Fatura kesildikten sonra bakım-onarım yapım işi belgesi tanzim edilerek ödeme yapılmak üzere maliye şube müdürlüğünce kontrol yapıldıktan sonra ödemede sakınca bulunmadığından muhasebe müdürlüğüne evraklar gönderilmiştir.

\subsubsection{Bina / Çatı Bakım ve Onarımı Vakasının Doğrudan Temin Süreci} Açısından Değerlendirilmesi

KİK'da doğrudan temin bir ihale yöntemi olmadığından doğrudan temin alımlarının ne şekilde yürütüleceğine ilişkin bir hüküm olmamakla birlikte, uygulamada kurumların en az üç teklif alması gerektiğine ilişkin olarak da hiçbir madde veya cümle yoktur. Mevzuatta harcama / ihale yetkilisi piyasa fiyat araştırması yapılacak kişi veya firmaların sayısına karar verir şeklinde belirtilmektedir. Yine piyasa fiyat araştırması için görevlendirilecek personelin kim olacağına veya sayısına ihale yetkilisi karar verebilecektir şeklindeki ifade nedeniyle mevzuatın açık olmadığı ve sorumluluğu harcama / ihale yetkilisine verdiği görülmektedir.

Kurumda, kurum içi yönerge ve emirlerle yapım ve hizmet alımları sürecinde doğrudan teminde karşılaşılan yasal boşluklar için bu açıklar kapatmaya çalışmaktadır. Bu vakada kurumun yayımladığı 2019 yılı birinci altı aylık teftiş sonuç raporuna göre tüm yapım ve hizmet alımı işlemlerinde tedarik sürecine başlamadan önce ayrıntılı keşif raporu düzenlenmesi gerekirken bu kural ihmal edilmiş ve firmaların inisiyatifinde işin fiyatlandırılmasına sebep olmuştur. Ayrıca hak ediş raporunun tanziminde teknik personel (mühendis veya tekniker) görevlendirmesi yapılmadığından, işin tam ve sağlam olarak teslim alındığı tespit edilmeden hak ediş raporu düzenlenerek firmaya ödeme yapılmıştır.

Doğrudan temin KİK'nın 22'inci maddesi kapsamında olduğundan ve Kanun'un 18'inci maddesinde sayılan ihale usulleri arasında yer almadığından ihaleye fesat karıştırma vb. suçlar oluşmamaktadır. Aynı nedenlerle doğrudan temin alımları ile alakalı KİK tetkik yetkisi bulunmamaktadır. Türk Ceza Kanunu kapsamında değerlendirildiğinde ise tedarik sürecinde yer alan görevlilerin menfaati ve çıkarı olmadığında ceza kanunu kapsamında yer alan zimmet, irtikâp vb. suçlar oluşmamıştır.

\section{Sonuç}

4734 sayılı KİK'da doğrudan temin alım yöntemini düzenleyen 22'inci maddesi hile riskini önleyici temel ilkeleri taşımamaktadır. Kanunun bu açığını harcama yetkilisi doldurmaya çalışmaktadır. Bununla birlikte harcama yetkilisi de yönetmekte olduğu kamu kurumunun faaliyetlerini etkili, verimli ve hızlı bir şekilde gerçekleştirmek için tedarik yetkililerine sınırsız yetki vermektedir. Tedarik yetkilileri ise bu sınırsız yetki karşısında rahat hareket etmekte ve zaman zaman kanuna uygun olmayan hareketlere başvurabilmektedir. 
KİK gerekçelerini içeren TBMM 794 sayılı Komisyon Raporu KİK'nın 22'inci maddesinin gerekçe açıklamasında işin doğası gereği ilan yapılmaksızın ihtiyacın belirli bir istekliden karşılanmasının kaçınılmaz olduğu durumlar dikkate alınarak düzenleme yapmıştır. İdarelerin ihtiyaçlarını en uygun şekilde karşılamasını sağlamak üzere, isteklilerle teknik şartlar ve fiyat üzerinde görüşme yapması mümkün kılınmıştır. Bu bağlamda doğrudan temin alım yöntemi amacına hizmet etmektedir. Ancak harcama yetkilisine sınırsız takdir yetkisi verilmesi ve gerçekleştirme sürecinde gerçekleştirme görevlilerinin görevlerini icrasında ihmalkâr davranışları doğrudan alım yöntemini hile riski açısından riskli hale getirmektedir.

Kamu alımlarında hile riskini tamamen ortadan kaldırma çabası çok fazla mevzuat değişikliği yapılmasını gerektirecektir. Sonrasında bürokrasinin artması ve kamu kurumlarında mal ve hizmet alım sürecinin yavaşlaması ile kırtasiyeciliğin artmasına sebebiyet vereceği söylenebilir.

Kamu kurumlarına sadece, çok acil ve elzem ihtiyaçlarının kendi bölgelerinde tedarik edilmesine yetki verilmelidir. Bu ihtiyaçların tespitinde de yetki taşradaki kamu kurumlarına verilmemeli her kurumun ihtiyaçları işlevlerine göre değişkenlik gösterdiğinden kurumların merkez teşkilatlarınca her mali yılbaşında yayımlanmalıdır. Kamusal tedarik sisteminde merkezileşmeye gidilmesi kamusal tedarik sistemin kontrol ve teftişini kolaylaştıracaktır. Ayrıca bu sistem kırtasiyeciliği en az seviyede tutacak ve taşra kamu kurumlarında harcama yetkilisinin tekelci görünümünü ortadan kaldıracaktır.

İncelenen kamu kurumunun merkez teşkilatında bulunan ve doğrudan tepe yöneticisine bağlı müfettişler ile her mali yılın tüm kamu alımları, muayene, sarf ve kayıt silme evraklarının tamamı incelenmektedir. Bu durum harcama yetkilisinin takdir yetkisini mevzuat ve kurum için yönergelerin dışına çıkmasına engel olmaktadır. Ayrıca incelenen kurumun tüm büyük ölçekli alımları (kıyafet, silah, hareketli araç, bilgisayar vb.) Ankara, İstanbul ve İzmir ilinde bulunan tedarik merkezlerince alımı yapılmaktadır. $\mathrm{Bu}$ işleyiş taşradaki harcama yetkilisine kamusal harcama sınırı koymakta ve yetkilerini sınırlamaktadır.

Kurumda ihale usulü ile yapılacak alımlarında hata ve hile riskini azaltmak veya ortadan kaldırmak için verilebilecek önerilerin başında görevlendirilecek harcama yetkilisinin ve gerçekleştirme görevlilerinin yetki sınırlarının net bir şekilde ortaya konulması gelmektedir. Diğer bir çözüm önerisi ise doğrudan temin alım yönteminin uygulamasında çelişkiye yer vermeyecek mevzuat değişikliğine gidilmesidir. Yöntemin her aşamasının örneklendirilerek yönetmeliğin revize edilmesi ile uygulama aşamasında yaşanabilecek sıkıntıların önüne geçilebileceği düşünülmektedir. 
Ticari ilişkilerin ve pazarın online ortama taşındığı ve artık ulusal değil uluslararası alışverişlerin kolayca yapılabildiği günümüzde, kamu alımlarının daha dinamik bir yapıya kavuşturulması gerekmektedir. Bu kapsamda online alışverişe açılan Devlet Malzeme Ofisinin daha fazla ürün hatta hizmet/yapım işlerini karşılayabilecek satışları yapabilmesine henüz yeni izin verilmekle birlikte kısıtlı düzeydedir. Kamu kurumlarına sadece, çok acil ve elzem ihtiyaçlarının kendi bölgelerinden tedarik edilmesine yetki verilmelidir. Bu ihtiyaçların belirlenmesinde de yetki taşradaki kamu kurumlarına verilmemeli her kurumun ihtiyaçları işlevlerine göre değişkenlik gösterdiğinden kurumların merkez teşkilatlarınca her mali yılbaşında yayımlanmalıdır. Kamusal tedarik sisteminde merkezileşmeye gidilmesi kamusal tedarik sistemin kontrol ve teftişini kolaylaştıracaktır. Sayıştay Başkanlığı'nın denetimlerin örneklem yoluyla yapılma yönteminden tüm tedarik evrenin kontrolüne imkân verecektir. Bu kapsamda taşrada son on yıldır hiç Sayıştay denetimine alınmayan kamu kurumları bulunmaktadır. Sisteme uyum konusunda kamu kurumlarınca problem yaşanacak olsa da zamanla problem odaklı çözümlerle sisteme uyum sağlanacağı düşünülmektedir. 


\section{KAYNAKÇA}

Akdoğan, Muzaffer (2014), “Avrupa Birliği Kamu Alımları Direktifi ve Türkiye Uygulaması Yansımasının İlerleme Raporları Işığında Değerlendirilmesi’’, İstanbul Üniversitesi Hukuk Fakültesi Mecmuası, C:16, ss.1-20.

Atılbaz, Yıldıray (2009), 4734 Sayılı Kamu İhale Kanunu Kapsamında Doğrudan Temin Ile Yapılacak Alımlarda ki Uygulamaların Analizi, Yayınlanmamış Yüksek Lisans Tezi, Bahçeşehir Üniversitesi Fen Bilimler Enstitüsü, İstanbul.

Atuğ, Mustafa (2018), Kamu Satın Alımlarında Doğrudan Temin Uygulamaları ve Kanuna Aykırı Davranışlar Kapsamında Değerlendirilmesi, Yayınlanmamış Yüksek Lisans Tezi, Uşak Üniversitesi Sosyal Bilimler Enstitüsü, Uşak.

Aytaç, Deniz (2004), Türkiye’de Konsolide Bütçe Harcamalarının Gelişimi, Avrupa Birliği Ülkeleri İle Bir Karşılaştırma, Yayınlanmamış Yüksek Lisans Tezi, Ankara Üniversitesi Sosyal Bilimler Enstitüsü, Ankara.

Baskan, Tuba, D. (2013). Muhasebe Hata ve Hilelerinin Önlenmesinde Bağımsız Denetimin Rolü ve Etkinliği: Bir Uygulama. Doktora Tezi. Kırıkale: Kırıkale Üniversitesi Sosyal Bilimler Enstitüsü.

Başbakanlık Mevzuatı Geliştirme ve Yayın Genel Müdürlüğü, (2003, 30 Temmuz). Bazı Kanunlarda Değişiklik Yapılması Hakkında Kanun, Resmi Gazete Kanun No: 4964, https://www.resmigazete.gov.tr/eskiler/2003/08/20030815.htm

Bozkurt, Nejat. (2016). İşletmelerin Kara Deliği Hile 'Çalışan Hileleri' (3.b.). İstanbul: Alfa Basım Yayım.

Büber, Bülent (2008), Yeni Bir Çatışma Alanı: Kamu Alımları, Yayınlanmamış Doktora Tezi, Ankara Üniversitesi Sosyal Bilimler Enstitüsü, Ankara.

Çatıkkaş, Özgür ve Ercan Çalış, "Hile Denetiminde Proaktif Yaklaşımlar", Muhasebe ve Finansman Dergisi, Say1: 45, Ocak 2010, ss. 146- 156.

Damga Vergisi Kanunu, (1964, 11 Temmuz). Resmi Gazete (Say1: 11751). https://www.mevzuat.gov.tr/MevzuatMetin/1.5.488.pdf

Demir, Çağla (2019), Kamu İhale Mevzuatının Değişim Ve Gelişim Süreci Çerçevesinde 4734 Sayılı Kamu İhale Kanununun Değerlendirilmesi, TURAN-SAM Uluslararası Bilimsel Hakemli Dergisi, Cilt: 11/Sonbahar, Say1: 44, ss: 587-591, https://www.turansam.org/TURAN-SAM_44.pdf

Ekşi, Hakkı (2013), Kamu Harcamaları Kapsamında Kamu İhale Sisteminin Yolsuzluk Suçları Açısından Değerlendirilmesi, Yayınlanmamış Yüksek Lisans Tezi, Uludağ Üniversitesi Sosyal Bilimler Enstitüsü, Bursa.

Ertaş, Cem R. (2010), Kamu Kaynaklarının Etkin Kullanımı Açısından Kamu İhale Kanununda Öngörülen İhale Usullerinin İncelenmesi ve Değerlendirilmesi, Yayınlanmamış Yüksek Lisans Tezi, Gazi Üniversitesi Sosyal Bilimler Enstitüsü, Ankara.

Kaplan, Sami (2012), "İdeal Bir Kamu İhale Kanunu ve İdeal Bir Kamu İhale Kurumu ve Kurulu Nas1l Olmalıdır? Fonksiyonel Bir Model Çalışması', Maliye Dergisi, S:162, ss.18-50.

KGK, Kamu Gözetimi ve Denetimi Kurumu (2013). BDS-240 (Bağımsız Denetim Standardı 240) Finansal Tabloların Bağımsız Denetiminde Bağımsız Denetçinin Hileye İlişkin Sorumlulukları,http://kgk.gov.tr/Portalv2Uploads/files/PDF\%20linkleri/standartlar\%20ve\%20ilke\%20k $\operatorname{ararlar} \% \mathrm{C} 4 \% \mathrm{~B} 1 / \mathrm{DENET} \% \mathrm{C4} \%$ B0M\%20STANDARTLARI/BDS_240.pdf, Erişim tarihi: 14.06.2020

KİK, 4735 Sayılı Kamu İhale Sözleşmeleri Kanunu ( 2002, 22 Ocak). Resmi Gazete (Sayı: 24648). https://www.mevzuat.gov.tr/MevzuatMetin/1.5.4735.pdf

KİK, (2019), “Kamu Alımları İzleme Raporu: 2018” Kurumsal Gelişim Ve Araştırma Dairesi Başkanlı̆̆ı, Ankara.

https://dosyalar.kik.gov.tr/genel/Raporlar/Kamu_al\%C4\%B1mlar\%C4\%B1_izleme_raporu_2018_y\%C 4\%B11sonu_rev8.pdf

KİK, (2018), "Kamu Alımları İzleme Raporu: 2017” Kurumsal Gelişim Ve Araştırma Dairesi Başkanlığı, Ankara.

http://dosyalar.kik.gov.tr/genel/Raporlar/2017_kamu_al\%C4\%B1mlar\%C4\%B1_izleme_raporu_rev3.pdf

KİK, (2017), "Kamu Alımları İzleme Raporu: 2016” Kurumsal Gelişim Ve Araştırma Dairesi Başkanlığı, Ankara.

http://dosyalar.kik.gov.tr/genel/Raporlar/kamu_alimlari_izleme_rapor_2016_y\%C4\%B1lsonu.pdf

KİK, (2015), “Kamu Alımları İzleme Raporu: 2015” Kurumsal Gelişim Ve Araştırma Dairesi Başkanlığı, Ankara.

http://www2.ihale.gov.tr/Duyurular2012/2015_alt\%C4\%B1_yl\%C4\%B1k_kamu_al\%C4\%B1m\%C4\%B1_istati stik_raporu_v6.pdf

KİK, (2015), “Kamu Alımları İzleme Raporu: 2014” Kurumsal Gelişim Ve Araştırma Dairesi Başkanlığğ, Ankara.

http://www2.ihale.gov.tr/Duyurular2012/2014_kamu_alimlari_raporu.pdf 
KİK, Kamu İhale Kanunu (2002, 22 Ocak). Resmi Gazete (Say1: 24648). https://www.mevzuat.gov.tr/MevzuatMetin/1.5.4734.pdf

KMYKK, Kamu Mali Yönetimi ve Kontrol Kanunu ( 2003, 24 Aralı). Resmi Gazete (Sayı: 25326). https://www.mevzuat.gov.tr/MevzuatMetin/1.5.5018.pdf

Küçük, İ. (2008). Finansal Raporlamada Hile-Manipülasyonlar ve Önlenmesi. Doktora Tezi. İstanbul: Marmara Üniversitesi Sosyal Bilimler Enstitüsü.

Mal Alımları Denetim Muayene Ve Kabul İşlemlerine Dair Yönetmelik (2002, 19 Aralık). Resmî Gazete (Sayı: 24968).

https://www.mevzuat.gov.tr/File/GeneratePdf?mevzuatNo=4713\&mevzuatTur=KurumVeKurulusYonet meligi\&mevzuatTertip $=5$

MYHBY, Merkezi Yönetim Harcama Belgeleri Yönetmeliği (2005, 31 Aralık). Resmi Gazete (Sayı: $26040,3$. Mükerrer),

https://www.mevzuat.gov.tr/File/GeneratePdf?mevzuatNo=9815\&mevzuatTur=KurumVeKurulusYonet meligi\&mevzuatTertip $=5$

Özer, Barış (2015), Türkiye'de Kamu Harcama Sürecinde Uygulanan Tedarik Usullerinin Yolsuzluk Riski Açısından Analizi, Yayınlanmamış Yüksek Lisans Tezi, Celal Bayar Üniversitesi Sosyal Bilimler Enstitüsü, Manisa.

Pehlivanlı, Davut. (2011). Hile Denetimi Metodoloji ve Raporlama. İstanbul: Beta Basım Yayım.

Resmi Gazete, (2020),Kamu Kurum ve Kuruluşlarının İhtiyaçlarının Devlet Malzeme Ofisi Genel Müdürlüğünce Karşılanması Hakkında Karar, Karar No:2645, Sayı:31151, https://www.resmigazete.gov.tr/eskiler/2020/06/20200610-4.pdf

Strateji ve Bütçe Başkanlığı, (2019), Analitik Bütçe Sınıflandırmasına İlişkin Rehber, http://www.sbb.gov.tr/wpcontent/uploads/2019/04/AnalitikEkorehber_2019-2021.pdf

Topal, Aysun (2016). Bilecik İl Özel İdaresinde Dış Kaynak Hizmet Alımı; Sorunlar Ve Çözüm Önerileri, Yayınlanmamış Yüksek Lisans Tezi, Bilecik Şeyh Edebali Üniversitesi, Sosyal Bilimler Enstitüsü, Bilecik.

Üstün, Ümit S. ve Çalış, Hande S. (2019). 4734 Sayılı Kamu İhale Kanununda Doğrudan Temin Usulü. Selçuk Üniversitesi Hukuk Fakültesi Dergisi, 27 (1), ss:11-36.

Yavuz, Nurettin (2018). Kamu İhale Kanunu Çerçevesinde Doğrudan Temin Yöntemi Ve Değerlendirilmesi, Yayınlanmamış Yüksek Lisans Tezi, Eskişehir Osmangazi Üniversitesi Sosyal Bilimler Enstitüsü, Eskişehir. 